\title{
ФОРМУВАННЯ НАУКОВО-ДОСЛІДНИЦЬКОЇ КОМПЕТЕНТНОСТІ СТУДЕНТІВ У СУЧАСНОМУ НАВЧАЛЬНОМУ ПРОЦЕСІ
}

О. М. Камишний

\author{
Запорізький держсавний медичний університет
}

\section{FORMATION OF SCIENTIFIC AND RESEARCH COMPETENCE OF STUDENTS IN MODERN EDUCATIONAL PROCESS}

\author{
O. M. Kamyshny
}

\author{
Zaporizhzhia State Medical University
}

\begin{abstract}
У статті акцентовано увагу на особливостях формування науково-дослідницької компетенції студентів у процесі викладання мікробіології в медичних університетах як однієї із складових професійної компетентності майбутніх фахівців.

In article we discusses some aspects of microbiology teaching in medical high school. It covers the formation of the scientific and research competence of students in education. It is one of the components of professional competence of future specialists.
\end{abstract}

Вступ. На сучасному етапі розвитку інформаційного суспільства в Україні перед колективами вищих навчальних закладів гостро постають завдання не тільки здійснення ефективного професійного навчання майбутніх фахівців, але й виховання грамотних, конкурентоспроможних, духовно багатих, національно свідомих, творчих особистостей, рівень знань котрих відповідав вимогам суспільства, що постійно підвищуються [1]. Тому новою парадигмою освіти є компетентнісний підхід, який надає сьогодні широкі можливості для формування та розвитку професійної компетентності студентів медичних спеціальностей під час їхнього навчання у вищих медичних навчальних закладах $[1,2]$. На сьогодні постає задача майже кожного студента-медика зробити науковим дослідником, адже такі здатності $є$ основою для продовження навчання протягом усього життя, його успішної професійної діяльності, побудови власної траєкторії самореалізації у майбутній професії, розвитку та суспільного визнання [3].

Зміни останніх років у галузі вищої освіти наголосили на контрасті між сформованими традиціями й інноваціями в організації навчального процесу та зумовили необхідність впровадження сучасних інноваційних освітніх технологій для розвитку педагогічного процесу, зокрема інформаційно-комунікативної технології навчання, що набула поширення у практиці навчально-виховного процесу у вищих навчальних

(c) О. М. Камишний закладах $[2,3]$. Головна мета технології полягає у створенні умов для розвитку особистості майбутнього професійного лікаря, здатності розв'язувати складні нестандартні задачі, стимулювання творчої, самоосвітньої і дослідницької діяльності [3]. Тому у контексті професійної підготовки медичного працівника отримані знання й уміння набувають особливого значення, але посилення наукової складової у навчальному процесі медичних вишів виявляє проблему формування науково-дослідницької компетентності як однісїз ключових компетентностей майбутніх фахівців і професійних якостей лікаря, і рішення зазначеної проблеми не втрачає актуальності до сьогодні $[3,4]$. Отже, мета статті полягає в розкритті особливостей формування науково-дослідницької компетентності студентів на прикладі вивчення навчальної дисципліни "Мікробіологія, вірусологія, імунологія" у Запорізькому державному медичному університеті.

Основна частина. На сьогодні удосконалення навчального процесу та підвищення якості підготовки студентів $€$ пріоритетним завданням кафедри мікробіології, вірусології та імунології. А вдале поєднання сучасних інноваційних технологій при викладанні навчального матеріалу з дисципліни "Мікробіологія, вірусологія, імунологія" " д дослідницькою діяльністю студентів, яка $\epsilon$ підгрунтям формування науководослідницької компетентності майбутніх фахівців, підвищує інтерес до цієї дисципліни, активізує навчальнопізнавальну діяльність. На думку багатьох дослідників і педагогів, формування науково-дослідницької 
компетенції здійснюється в умовах системності та безперервності освітнього процесу (Е. Н. Гусинський, М.В.Кларін, Г. П. Щедровицький), технологічності (Н. В. Кузьміна, Л. М. Мітіна) і прогнозованості результату навчання (Н. А. Амінов, Б. С. Гершунський, В. А. Семиченко) [4]. Тому для забезпечення цілісності процесу формування вищезазначеної компетентності інноваційна діяльність співробітників кафедри мікробіології, вірусології та імунології ЗДМУ була спрямована на впровадження активних форм і методів навчання на практичних заняттях та лекціях, організації самостійної роботи студентів з урахуванням індивідуально-психологічних особливостей особистості, що забезпечують успішність і якісну своєрідність процесу пошуку, придбання, осмислення та прогнозу результатів отриманих нових даних. Під час застосування методів активного та проблемно-орієнтованого навчання, таких, як “мозковий шторм”, кейс-метод, “круглі столи”, презентації, ігрове моделювання, метод проектів, оцінюються не стільки певні знання, скільки вміння студентів аналізувати ситуацію, творчо застосовувати набуті знання, логічно мислити, приймати відповідні рішення [5]. Наприклад, на практичних заняттях з мікробіології для студентів спеціальностей "Лікувальна справа" та "Педіатрія" використовується проектне навчання як один із методів проблемноорієнтованого навчання з використанням комп'ютерних технологій. У межах методики відбувається самостійний відбір наукового матеріалу проблемного змісту і подальше його відтворення студентами у різних ситуаційних завданнях з мікробіологічної діагностики окремої інфекційної хвороби, а також обов'язковим компонентом інтегрованого рішення проблеми є виконання практичної частини дослідження з обраної теми. А студенти спеціальності “Лабораторна діагностика” виконують завдання дослідницького характеру в період виробничої практики.

Перспективним напрямком організації навчальної дослідницької роботи є створення на кафедрі навчальнонаукової мікробіологічної лабораторії, в якій ведуться наукові дослідження та одночасно організується науково-дослідницька робота студентів. В цілому, науково-дослідницька робота студента включає три стандартних етапи [5, 6]: проектувальний етап включає методологічний і організаційний розділи та передбачає створення попередньої узагальненої моделі дослідження. Методологічний розділ включає постановку проблеми дослідження, іiі реальність існування, розробленість сучасною наукою, актуальність, а також визначення мети, завдань, об'єкта і предмета дослідження, уточнення основних понять, висунення робочих гіпотез, операції з поняттями, тоді як організаційний розділ містить відомості про вибір або розробку методів роботи з відомостями та фактами за темою наукового дослідження. Особливої уваги заслуговує робота з поняттями, формування визначень та їх класифікація, адже від того, який зміст вкладається в поняття, багато в чому залежить ефективність дослідження, реалізація його цілей і завдань. На інформаційному етапі студент-дослідник опрацьовує масиви емпіричних даних, які відбирає, систематизує, описує, узагальнює. Ці дані в подальшому стануть основою для підтвердження, обгрунтування або скасування зазначених наукових гіпотез. Крім того, для успішної роботи потрібні уміння і навики користуватися різними джерелами фактів. Використання сучасних інформаційно-комунікативних технологій (IKT), зокрема комп'ютерних, й мережі Інтернет у навчальному процесі дають змогу застосувати електронні каталоги, які забезпечують більш широкі можливості пошуку, зберігаючи час дослідника. Такі каталоги має Національна бібліотека України імені В. I. Вернадського (http://www.nbuv.gov.ua/), але можна здійснювати пошук, наприклад, через сайти електронних бібліотек: Google Book Search-світова електронна бібліотека книг; www.elibrary.ru - сайт наукової електронної бібліотеки; HighWire Press підрозділ бібліотеки Стенфордського університету; www.thecochranelibrary.com The Cochrane Library Кокранівська бібліотека; www.rsl.ru - сайт російської державної бібліотеки; www.scsml.rssi.ru - Центральна наукова медична бібліотека ММА ім. I. М. Сеченова; www.gpntb.ru, www.sigla.ru - системи пошуку книг в електронних бібліотеках [6]. Також дослідникам важливо знати про існування науково-орієнтованих пошукових систем, наприклад Scirus, які містять наукові, навчальні, технічні і медичні дані (найновіші звіти, рецензовані статті, патенти, препринти і журнали), Google Scholar, який забезпечує простий спосіб пошуку наукової літератури; з використанням тематичних каталогів, таких, наприклад, як UAport (http:// www.uaport.net/UAcatalog/), "Російська наукова мережа" (http://www.nature.ru/); а також через перегляд баз даних пошуку медичної інформації: PubMed, PubMed Central, MEDLINE - база даних медичної інформації, що включає бібліографічні описи із понад 4800 медичних періодичних видань з усього світу, PreMEDLINE; через перегляд та підписку на електронні періодичні видання, наприклад, на сайті WiseSoft http://www.wisesoft.ru/), FreeBooks4Doctors http:// www.freebooks4doctors.com/, Free Medical Journals 
http://www.freemedicaljournals.com/; BioMed Central http://www.biomedcentral.com/ [6, 7]. Результатом виконання даного етапу дослідження $є$ складання оглядів та реферування літературних джерел по обраній темі. Аналітичний етап науково-дослідницької діяльності передбачає упорядкування результатів дослідів, ï обробку, аналіз даних та виділення причиннонаслідкових зв'язків між ними, обгрунтовування закономірностей, а також порівняння результатів теоретичного та експериментального досліджень за допомогою синтезу й теоретичної інтерпретації експериментальних даних, одержаних у дослідах [5]. А етап інтерпретації наукових даних та представлення результатів спрямовано на оформлення наукової роботи за результатами дослідження у вигляді схем, графіків, таблиць, діаграм, презентацій та захист, а сучасні інформаційно-комунікативні технології на-

\section{Списоклітератури}

1. Закон України "Про Основні засади розвитку інформаційного суспільства в Україні на 2007-2015 роки" // Відомості Верховної Ради України (ВВР). - 2007. - № 12. C. 102-109.

2. Компетентнісний підхід у сучасній освіті: світовий досвід та українські перспективи: Бібліотека з освітньої політики / під заг. ред. О. В. Овчарук. - К. : “К.І.С.”, 2004. - 112 с.

3. Инновационные методы обучения в системе преподавания классических дисциплин / В. В. Зинчук [и др.] // Современные образовательные технологии и методическое обеспечение в высшей медицинской школе : материалы Республиканской конференции с международным участием. - Гродно, 2010. - С. 104-107.

4. Борисенко Л. Л. Психолого-дидактичні умови формування науково-дослідницької компетентності студентів еко- дають великі можливості їх візуалізації $[5,6]$. Формами підведення підсумків науково-дослідницької роботи студента може бути конкурс доповідей, участь у наукових конференціях і предметних олімпіадах, проведення круглих столів, зустрічі з вченими, а також публікація тез кращих робіт у наукових збірниках медичних вишів.

Висновки. Таким чином, науково-дослідницька робота студентів у сукупності з інформаційно-комунікативними технологіями виконує комплекс найважливіших освітніх, виховних, наукових і загальнокультурних функцій. Ця робота $€$ передумовою формування науково-дослідницької компетентності майбутніх фахівців, становлення цілісної і творчої активної особистості фахівця, підвищення ії наукового світогляду і професійної готовності.

номічних спеціальностей / Л. Л. Борисенко // Духовність особистості: методологія, теорія і практика. - 2014. №2 (61). - C. 45-54.

5. Нечепоренко Л. С. Про науково-дослідницьку роботу студентів: методичні рекомендації для студентів та аспірантів/ Л. С. Нечепоренко. - Харків : ХНУ, 2011.-20 с.

6. Золочевська М. В. Формування дослідницької компетентності при вивченні інформатики : методичний посібник / М. В. Золочевська. - Харків, 2009. - 92 с.

7. Бужинская Н. В. Формирование исследовательской компетентности студентов в процессе изучения информатики [Текст] / Н. В. Бужинская, Л. И. Миназова // Молодой ученый. -2013. -№ 1.-С. 34-38.

Отримано 25.11.14 